\title{
Research on Integrity Evaluation System of Food Brand Enterprises Based on the Creeds of Business Governance*
}

\author{
Xie Fan, Meng Yong \\ School of Management Administration, Shanghai University of Engineering and Science, Shanghai, China \\ Email: woshi1022@126.com; mengyong1992@163.com
}

Received November 20, 2013; revised December 22, 2013; accepted January 7, 2014

Copyright (c) 2014 Xie Fan, Meng Yong. This is an open access article distributed under the Creative Commons Attribution License, which permits unrestricted use, distribution, and reproduction in any medium, provided the original work is properly cited. In accordance of the Creative Commons Attribution License all Copyrights @ 2014 are reserved for SCIRP and the owner of the intellectual property Xie Fan, Meng Yong. All Copyright (C) 2014 are guarded by law and by SCIRP as a guardian.

\begin{abstract}
Under today's market environment, the brand is an important intangible asset to enterprises. If the brand is certain to win in the market, the first condition is to establish a good image of integrity and makes it firmly rooted in the minds of consumers. In recent years, a spate of food brands lacking of integrity events shocked the nation and the world which make people's health, and economic development under serious threat. How to evaluate the integrity of the food brands, find out the reason for lacking of integrity and provide a reference to the integrity system construction of food brand enterprises are the main content of this paper. This paper is based on the Creeds of Business Governance in Oriental Management theory and builds integrity indicator system according to the four ethics-honesty, trustworthiness, justice and benevolence. AHP is utilized to calculate the index weight to make the integrity evaluation system with scientific and operability.
\end{abstract}

\section{KEYWORDS}

\section{Food Brand; Brand Integrity; Creeds of Business Governance; Integrity Evaluation System}

\section{Introduction}

In today's world, the brand, an important intangible asset to companies, conveys the business-to-consumer commitment. Integrity is the fundamental principle of the core values of the brand. Under the circumstance of economic globalization and intense competition in the market environment, the global market share has brought great prosperity to commodities. To be sure of success in the market, the brand should establish a good image of integrity and make it firmly rooted in the minds of consumers in the first place. However, recent outbreaks of food safety incidents of food brands, such as Guan Sheng Yuan event, Sanlu melamine incident, Shuanghui clenbuterol event, Sanquan dumplings bacteria events, reflect the missing of brand integrity in some of Chinese com-

\footnotetext{
*This paper is one of the achievements of the key research project of Shanghai Education Commission: Research on the "people-oriented" management mode of state-owned enterprises (No.: B-8901-11-00812ZS175); School of graduate innovation project: Research on Integrity of food brand enterprises-An Empirical Study of the theory of Oriental Management (No.: A-0903-13-01044).
}

panies. Food safety incidents resulting from brands dishonesty may cause great harm mainly expressed in three aspects: First, food safety incidents of brand companies mainly relate to excessive trust with consumers, rather than with consumer income levels and identify ability. Therefore, food safety accidents of brand enterprises may cause serious harm to consumers' confidence, resulting in trust missing of market and society. Second, brands integrity missing may lead to the decline in market demand, lower brand profits and unsustainability. According Shuanghui 2011 semi-annual development report, the company achieved net profit of 75.98 million yuan from January to June, $84.85 \%$ lower than the same period of previous year. Clenbuterol event responsible for the sales and performance declines in the first half year ${ }^{1}$. Third, brands integrity missing may impact the international image of China's food safety and food foreign trade development. According to customs statistics, affected by the Sanlu "melamine" incident, Chinese dairy exports

${ }^{1}$ Data sources: Shuanghui's Official website, 2011. http://www.shuanghui.net/html/category/news/ggxx/page/8 
fell $91.8 \%$ in October 2008, while the largest decline happened in milk powder which fell 99.2\% [1].

Frequent security incidents of food brands sparked thinking on corporate integrity issues, so exploring the integrity issue of food brands has an important role in reducing corporate food safety incidents, maintaining food brands and the image of the entire food industry. How to evaluate the integrity situation of the food brands, come up with effective measures to achieve improved food brand integrity and promote the sustainable development of food brands are the main subject.

\section{Literature Review}

\subsection{Review of the Brand Integrity Issues}

In the relationship between the brand and integrity, many domestic scholars have done related research: Lin Kai yong (2005) viewed from the economic ethics and integrity to explore the relationship between brand and integrity. He believes that integrity is the survival line of the brand and the cornerstone of brand development; brand is the embodiment and economic symbols of integrity [2]. Zhang Shuyun (2005) believed that the integrity runs throughout the entire brand shaping process and it is the most basic means to maintain the integrity and enhance the brand image [3]. Feng Jun (2006) pointed out that the relationship between the brand and integrity is that the brand is the carrier of integrity and integrity is the cornerstone of the brand [4]. Gao Wei (2008) took the idea that the brand is the crystallization of integrity behaviors of entrepreneurs, employees, government [5]. Zhu Yuzhen and Zhou Bochun (2010) thank that an integrity culture is a prerequisite for long-run of well-known brand and is also an important basis for the existence of famous brand. Integrity cultural can create communication ability of well-known brand [6]. Zhang Zhong (2012) believed that the integrity is the brand's core competitiveness and is the bridge of the brands cooperation and communication between brand and customer. Meanwhile, integrity can improve the organization cohesion, and promote the healthy development of the brand [7].

\subsection{Review of the Enterprise Integrity Evaluation System}

Many studies, domestic or abroad, concentrate on the integrity system, including related research in many fields, such as personal integrity system, integrity system department, company integrity system, government integrity system, social integrity system and so on. Although there are many literatures study on the integrity system, few on the system of food brand enterprises. Food business integrity evaluation criteria (2010) clearly shows the relevant definition of food business integrity and evaluation criteria and also build the foundation for establishment of the integrity evaluation system of food brands enterprise in this thesis [8]. Yue Guozhen (2011) gave a detailed corporate integrity evaluation methods and criteria, which points out lines for the evaluation of the integrity of the food brands [9]. Wu Xueyuan (2011) builded the food safety and integrity evaluation system and took food enterprises in Shijiazhuang as example [10]. Peng Dianxin and Zhou Changyin (2013) analyzed food business integrity conditions using the fuzzy comprehensive evaluation method [11]. These studies are just from one angle or using some quantitative methods to guide the evaluation of corporate integrity issues, but lacking of theoretical guidance on values.

\subsection{Creeds of Business Governance}

Oriental management founded by Professor Su Dongshui contains the system of "4-zhi”, including four areas: state governance, business governance, self governance and family governance. It not only covers all aspects of management practice, but also meets the Chinese Confucian inference logic of "self-cultivating; family-regulating; state-ordering and then the land great governed" [12]. The Business Governance theory in Oriental Management is based on the ethics of "moral is basic, and wealth lays behind” and moral principle of "honesty, integrity, justice, benevolence” as the philosophical core and takes the principle of accumulation as the center, followed by the discovery of the objective economic laws, and the resulted forecasting, strategic planning, marketing, personnel management, and quality management and so on.

Among them, the ethic principle of "honesty, integrity, justice, benevolence" reflects the requirements of the enterprise integrity profoundly and comprehensively. "Honesty", that is honest business, is the basic requirements of daily operations of the enterprise; "integrity", which emphasis on credibility, is the requirements of business and external stakeholders exchanges; “justice”, that is righteous usury, is to require companies to establish a correct philosophy and improving the ideological and moral qualities; "benevolence", that is the heart of humanity, is to require enterprises to be people-oriented, caring for employees, introducing genuine and affordable high-quality products and services, and actively undertaking the corresponding social responsibility and taking attention to social welfare. In this paper, establishing integrity evaluation system for food brands based on the theory of "honesty, integrity, justice, benevolence" has important theoretical and practical significance.

\section{Establishment of Integrity Evaluation System of Food Brands}

\subsection{Principles of Evaluation Index System}

The choice of food brands integrity evaluation indicators 
should follow the following principles:

1) Scientific Principles. Scientific Principles is the most basic principles in designing integrity evaluation index system. Following the scientific principles requires ensuring the correctness of each evaluation index connotations, the generalization of one or some integrity attribute, the determination of both quality and quantity.

2) Operability. Operability refers to the understandable of indexes expression methods and the convenient collection of data source under the premise of meeting the purpose of the evaluation.

3) Combination of quantitative and qualitative principles. Corporate integrity evaluation is necessary to pay attention to use quantitative methods to analyze in order to more accurately reflect the characteristics of the system and its movement variation. While some indicators are not easy or impossible to quantify, then they must be analyzed through reasoning and subjective judgments.

\subsection{Connotation of the Indicators}

According to the four core philosophy creeds of Business Governance theory, setting of integrity evaluation index of food brands business reflects business integrity status mainly from two aspects: one hand inspects the integrity of corporate behavior, including the "honesty"-honest business and "integrity" - emphasis on credibility; the other hand examines the potential whether companies can continue to maintain the integrity of the future behavior, including the "justice" — take advantage of righteousness and "benevolence"-righteous usury. Therefore, food brands enterprise credit evaluation index system is divided into two parts: behavioral indicators and potential indicators. Integrity behavior is the main sector of integrity building and also can reflects the strengths and weaknesses of credit performance; while integrity potential is the momentum of sustainable integrity and development, which can in turn encourages enterprises to do better in law-obey, rule-obey and trustiness.

"Honesty" mainly inspects everyday operations of food brands business, including the following aspects:

1) Food quality and safety management systems and the corresponding organizational system.

2) Financial situation of enterprises: Food brands should comprehensively evaluate the financial position from the sound financial system, financial statements and audit reports and other aspects.

3) Production and operation files: including raw materials management, personnel management, plant design environment, production equipment, product processing procedures, packaging, product testing, product sales, product transport, service and other contents.

4) The relevant national certification: e.g. ISO9001, HACCP/ISO2000, GMP, ISO14001, laboratory accredi- tation, etc.

5) Self-discipline: investigating whether breach the industry rule, contract records and so on.

6) Brand Competitiveness: mainly inspect the brand development and marketing capabilities of food brands corporate, also concerning about the consumers' brand loyalty and trust [13].

7) Food safety management personnel.

"Trust" mainly inspects the credibility of food brands corporations when interaction with stakeholders, including the following aspects:

1) Corporate credits: the legal representative (or the actual controller) credit.

2) Business credit record: the integrity of state enterprises in the past.

3) Contract compliance: default records adjudicated by Arbitration body.

4) The implementation of relevant state policies and regulations.

"Justice" mainly inspects philosophy and ideological and moral qualities of food brands business, including the following aspects:

1) The establishment of enterprise credit management system: containing major integrity factors identification and dishonesty risk assessment, integrity management organization, procedures, programs and system, system running records, self-correction and implement improvement measures, and integrity management system of selfevaluation.

2) Integrity education and training.

3) Traceability system and recall system.

4) Environmental awareness and energy conservation measures.

"Benevolence" mainly inspects whether food brands corporations are able to be people-oriented and positively commit to undertake social responsibility, including the following aspects:

1) Personnel security: including a clear division of labor among the top managers, professional management and technical team and training plan and records.

2) Employee benefits: to pay pension, medical, unemployment, work injury, maternity insurance and employee housing provident fund, etc.

3) Social welfare: including agricultural help, poor support, charity donations and civilization education etc.

The concrete indexes are presented in Table 1 as follows:

\subsection{Using the AHP to Determine the Weight of Evaluation Index System}

The analysis method of AHP (Analytic Hierarchy Process) founded by American strategist T. L. Saaty is asimple decision method which combine qualitative and quantitative methods. The basic idea is to build a hierar- 
Table 1. Enterprises' integrity evaluation index table [14].

\begin{tabular}{|c|c|c|c|}
\hline Target layer & & Project layer & Program layer \\
\hline \multirow{18}{*}{$\begin{array}{l}\text { Integrity of } \\
\text { food brand } \\
\text { enterprise }\end{array}$} & \multirow{10}{*}{$\begin{array}{l}\text { Integrity } \\
\text { behavior }\end{array}$} & \multirow{7}{*}{$\begin{array}{l}\text { "Honesty"—honest } \\
\text { business }\end{array}$} & Food quality and safety management systems and the corresponding organizational system \\
\hline & & & Financial situation of enterprises \\
\hline & & & Production and operation files \\
\hline & & & The relevant national certification \\
\hline & & & Self-discipline \\
\hline & & & Brand Competitiveness \\
\hline & & & Food safety management personnel \\
\hline & & \multirow{4}{*}{$\begin{array}{l}\text { "Integrity"-emphasis } \\
\text { on credibility }\end{array}$} & Corporate credits \\
\hline & & & Business credit record \\
\hline & & & Contract compliance \\
\hline & \multirow{8}{*}{$\begin{array}{l}\text { Integrity } \\
\text { potential }\end{array}$} & & The implementation of relevant state policies and regulations \\
\hline & & \multirow{4}{*}{$\begin{array}{l}\text { “Justice"—take } \\
\text { advantage of } \\
\text { righteousness }\end{array}$} & The establishment of enterprise credit management system \\
\hline & & & Integrity education and training \\
\hline & & & Traceability system and recall system \\
\hline & & & Environmental awareness and energy conservation measures \\
\hline & & \multirow{3}{*}{ "Benevolence" } & Personnel security \\
\hline & & & Employee benefits \\
\hline & & & Social welfare \\
\hline
\end{tabular}

chical structure model which is internal independent and can describe complex problem simplifying complex issues. According to the two-two judgment on all levels of elements and make quantitative representation, then calculate the weight of each index and make the sort. Specifically, four steps are as follows:

1) Establishing the hierarchical structure model (Figure 1). According to the above analysis, the AHP model is divided into three layers. The target layer is the integrity of food brand enterprises; the second layer is the project level, including two aspects, namely, integrity behavior and integrity potential, which can be divided into four major treatment, that is honesty, integrity, justice and benevolence; the third layer is the program layer, it is the implementation of specific research projects.

2) Construction of the two-two comparison judgment matrix: matrix stands for comparison of relative importance between the layer and the related factors according to the former level factors. Such as:

First, taking the integrity of food brands $\mathrm{A}$ as the judgment matrix, structure the two-two comparison judgment matrix on the next layer elements-integrity behavior $\left(\mathrm{A}_{1}\right)$ and the integrity potential $\left(\mathrm{A}_{2}\right)$ as $\mathrm{A}=$ $\left(\mathrm{A}_{\mathrm{ij}}\right)_{n^{*} \mathrm{n}}$ :

\begin{tabular}{ccc}
\hline $\mathrm{A}$ & $\mathrm{A}_{1}$ & $\mathrm{~A}_{2}$ \\
\hline $\mathrm{A}_{1}$ & $\mathrm{a}_{11}$ & $\mathrm{a}_{12}$ \\
$\mathrm{~A}_{2}$ & $\mathrm{a}_{21}$ & $\mathrm{a}_{22}$
\end{tabular}

As to judgment matrix $A, a_{i j}>0, a_{i j}=, a_{i j}=1$.

Then, taking the element $A_{k}$ in the matrix as the judgment matrix, construct the comparison judgment matrix on the next layer elements $\mathrm{B}_{1}, \mathrm{~B}_{2}, \mathrm{~B}_{3}, \mathrm{~B}_{4}$ and then other layers successively.

To determine the quantitative importance of every in- dex by the method of AHP, the general method is $1-9$ scaling method. The scaling relation is shown in Table 2:

Each layer of judgment matrix:

$$
\begin{aligned}
& A=\left(\begin{array}{cc}
1 & 1.5 \\
0.6667 & 1
\end{array}\right) ; \quad A_{1}=\left(\begin{array}{ll}
1 & 1 \\
1 & 1
\end{array}\right) ; \quad A_{2}=\left(\begin{array}{cc}
1 & 1.5 \\
0.6667 & 1
\end{array}\right) ; \\
& \mathrm{B}_{1}=\left(\begin{array}{ccccccc}
1 & 0.5 & 0.3333 & 5 & 3 & 1 & 2 \\
2 & 1 & 0.5 & 3 & 4 & 1 & 2 \\
3 & 2 & 1 & 4 & 6 & 2 & 4 \\
0.2 & 0.3333 & 0.25 & 1 & 2 & 0.3333 & 1 \\
0.3333 & 0.25 & 0.1667 & 0.5 & 1 & 0.25 & 1 \\
1 & 1 & 0.5 & 3 & 4 & 1 & 4 \\
0.5 & 0.5 & 0.25 & 1 & 1 & 0.25 & 1
\end{array}\right) \\
& \mathrm{B}_{2}=\left(\begin{array}{cccc}
1 & 0.5 & 1 & 1 \\
2 & 1 & 2 & 2 \\
1 & 0.5 & 1 & 1 \\
1 & 0.5 & 1 & 1
\end{array}\right) ; \mathrm{B}_{3}=\left(\begin{array}{cccc}
1 & 3 & 1 & 2 \\
0.3333 & 1 & 0.3333 & 0.5 \\
1 & 3 & 1 & 2 \\
0.5 & 2 & 0.5 & 1
\end{array}\right) ; \\
& \mathrm{B}_{4}=\left(\begin{array}{ccc}
1 & 3 & 2 \\
0.3333 & 1 & 1 \\
0.5 & 1 & 1
\end{array}\right)
\end{aligned}
$$

3) The consistency check of judgment matrix (Table 3): $\mathrm{n}$ is the dimension of the matrix; $\lambda_{\max }$ is the largest eigenvalue of the matrix; C.I.= R.I. is the mean random consistency index (the values can be obtained through looking for R.I. referring table, Table 4),

C.R.=C.I./R.I. When C.R. $<0.10$, the result is passing, otherwise it is needed to re-adjust the judgment matrix element values. 


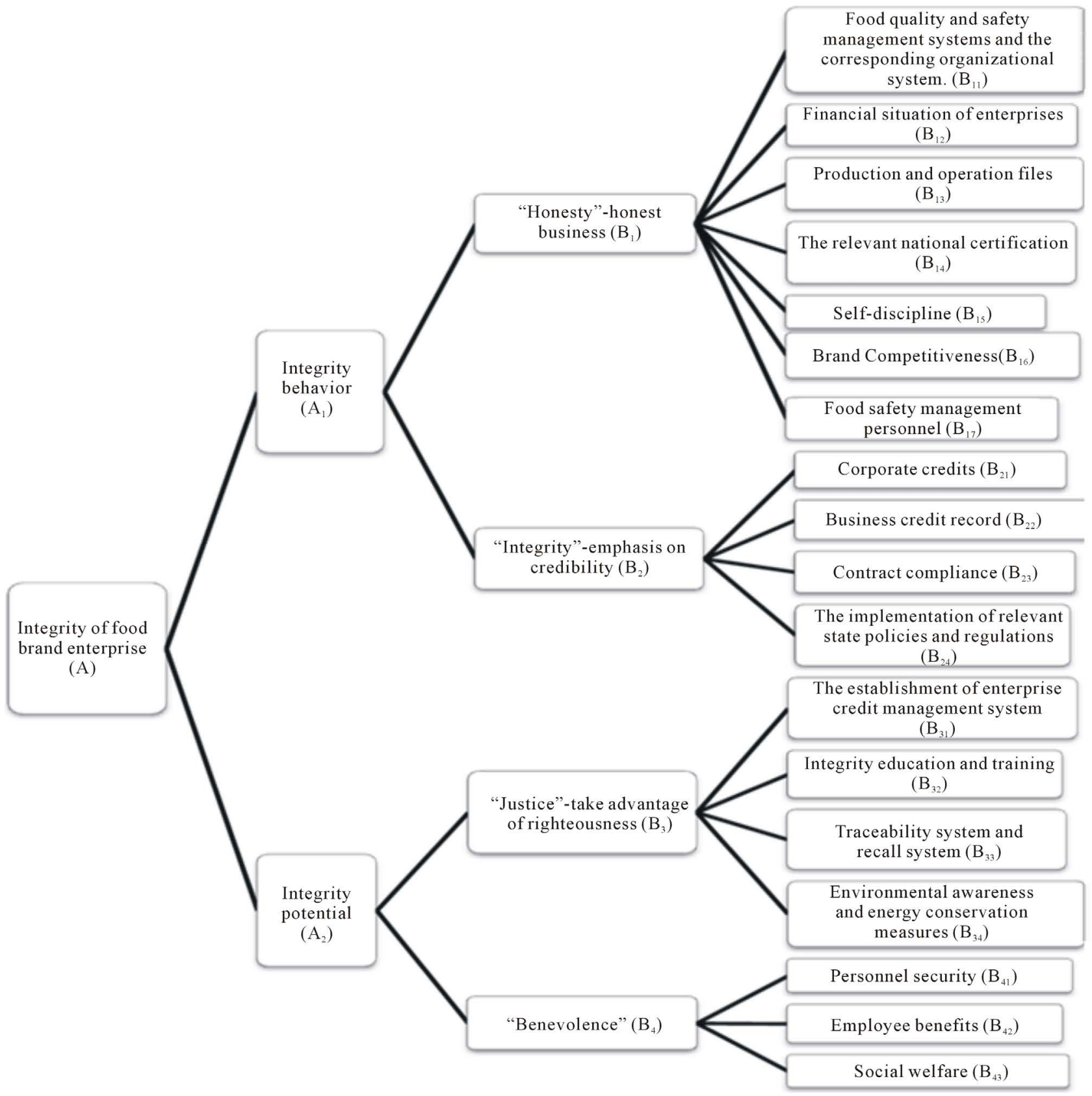

Figure 1. Hierarchical structure diagram of each index.

Table 2. The scaling relation table.

\begin{tabular}{cc}
\hline Scales & Meanings \\
1 & i and j are equally important factors \\
3 & i is slightly more important than $\mathrm{j}$ \\
5 & $\mathrm{i}$ is obviously more important than $\mathrm{j}$ \\
7 & $\mathrm{i}$ is more important than $\mathrm{j}$ \\
9 & $\mathrm{i}$ is absolutely more important than $\mathrm{j}$ \\
$2,4,6,8$ & Among the two odds \\
\hline
\end{tabular}

(4) To determine the weight: first calculating the products of each row element in the judgment matrixes $\mathrm{M}_{i}=\prod_{j=1}^{n} a_{i j},(i=1,2, \cdots, \mathrm{n})$; then for $\beta_{i}=,(i=1,2$, $W_{i}=\beta_{i} / \sum \beta_{i}$. Results are shown in Table 5.

\subsection{Scoring Method for Integrity Evaluation and Its Implementation}

As the processing and application for evaluation results, the indexes are transformed into the corresponding score 
Table 3. Consistency test results.

\begin{tabular}{ccccccc}
\hline Matrix & $\mathbf{n}$ & $\lambda_{\max }$ & C.I. & R.I. & C.R. & Results \\
\hline $\mathbf{A}$ & 2 & 2 & 0 & 0 & 0 & Pass \\
$\mathbf{A}_{\mathbf{1}}$ & 2 & 2 & 0 & 0 & 0 & Pass \\
$\mathbf{A}_{\mathbf{2}}$ & 2 & 2 & 0 & 0 & 0 & Pass \\
$\mathbf{B}_{\mathbf{1}}$ & 7 & 7.2406 & 0.0401 & 1.35 & 0.0297 & Pass \\
$\mathbf{B}_{2}$ & 4 & 4 & 0 & 0.89 & 0 & Pass \\
$\mathbf{B}_{3}$ & 4 & 4.0103 & 0.0034 & 0.89 & 0.0038 & Pass \\
$\mathbf{B}_{\mathbf{4}}$ & 3 & 3.0183 & 0.0092 & 0.52 & 0.0177 & Pass \\
\hline
\end{tabular}

Table 4. R.I. value table.

\begin{tabular}{cccccccc}
\hline $\mathrm{n}$ & 1 & 2 & 3 & 4 & 5 & 6 & 7 \\
\hline R.I. & 0.00 & 0.00 & 0.52 & 0.89 & 1.12 & 1.25 & 1.35 \\
\hline
\end{tabular}

$\cdots, n)$; And finally get the relative weight of each index after getting the weighted indexes. The comprehensive score of enterprise integrity is obtained according to the index weight of the integrity behavior and the integrity potential. The method is as follows:

The comprehensive score of enterprise integrity

$=$ integrity behavior score $* \mathrm{~W}_{1}$

+ integrity potential $* \mathrm{~W}_{2}$

$\left(\mathrm{W}_{1}, \mathrm{~W}_{2}\right.$ are the weights of integrity

behavior and integrity potential).

Integrity behavior evaluation score $=$

Honesty * corresponding weight

+ Integrity $*$ corresponding weight

Integrity potential evaluation score

$=$ Justice $*$ corresponding weight

+Benevolence $*$ corresponding weight

"Honesty" evaluation score $=$

$\sum$ (Honesty business senior index $*$ index weight)

"Integrity" evaluation score =

$\sum$ (Integrity senior index $*$ index weight)

"Judtice" evaluation score =

$\sum$ (Judtice senior index $*$ index weight)

"Benevolence" evaluation score $=$

$\sum$ (benevolence senior index $*$ index weight)

Break down the 100 points of Food enterprise's integrity behavior and integrity potential into the corresponding point of their subordinated index based on the weight. At the same time, in order to facilitate the score, the score is made appropriate adjustments. Specific value is described in Table 6.
After getting the final evaluation score, we determine the company integrity rate according to "three stages and nine ranks" classification method-the international integrity evaluate method. The specific contents are shown in Table 7.

\section{Example of Case}

Investigation and study are implemented on the integrity situation of a well-known food brands in a certain area. 200 questionnaires, recovery of 183, the recovery rate of 91.5\%, of which 174 questionnaires are valid, effective rate was $87 \%$. The investigation object includes 150 customers and 50 employees, the effective questionnaires were 125 copies and 49 copies, the valid questionnaires rates are $83.3 \%$ and $98 \%$. The consumers surveyed are of 16 - 68 years old. The male and female ratios are $62 \%$ and $38 \%$. According to the survey results, average score of every index are summarized in Tables 8 and 9 (The questionnaire sample can be seen in Appendix).

Using the Equation (1) and the result is as follows:

The comprehensive score of enterprise integrity

$$
\begin{aligned}
& =(41.5+45) * 60 \%+(51+34) * 40 \% \\
& =86.5 * 60 \%+85 * 40 \%=85.9
\end{aligned}
$$

Therefore, the credit rating of the enterprise is AA.

Table 5. The weight of each index results.

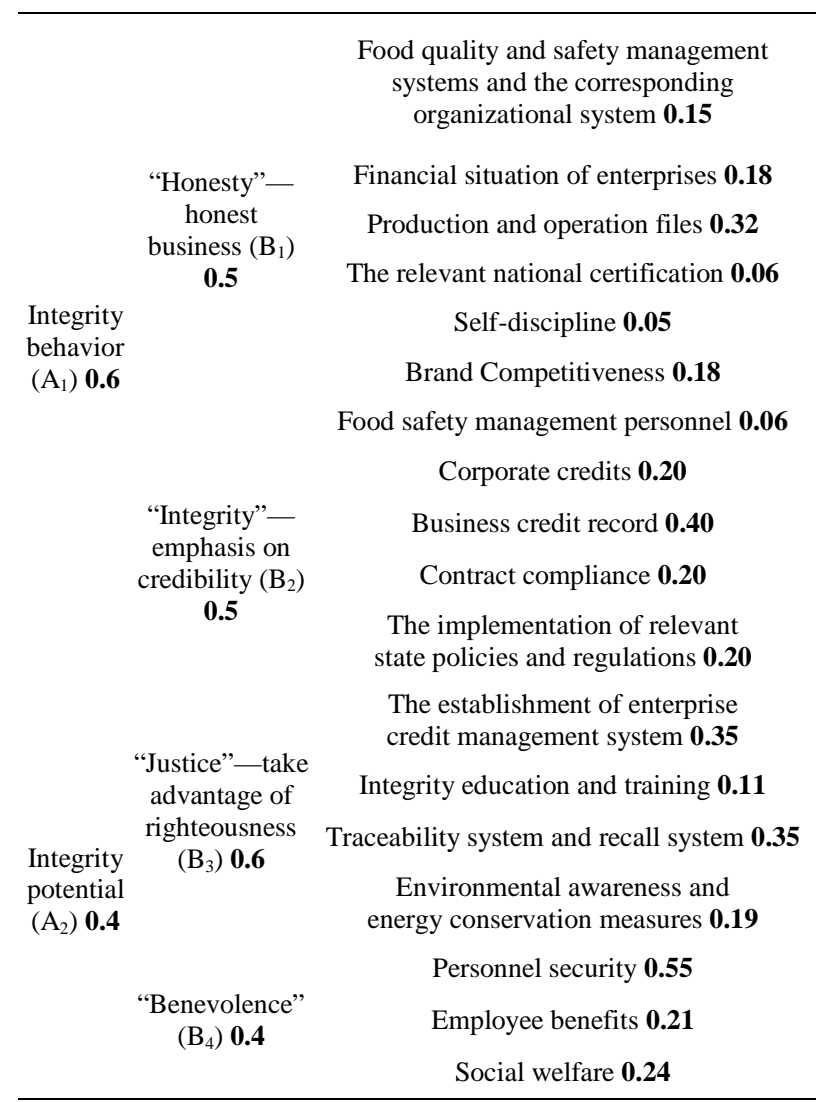


Table 6. The distribution of index score.

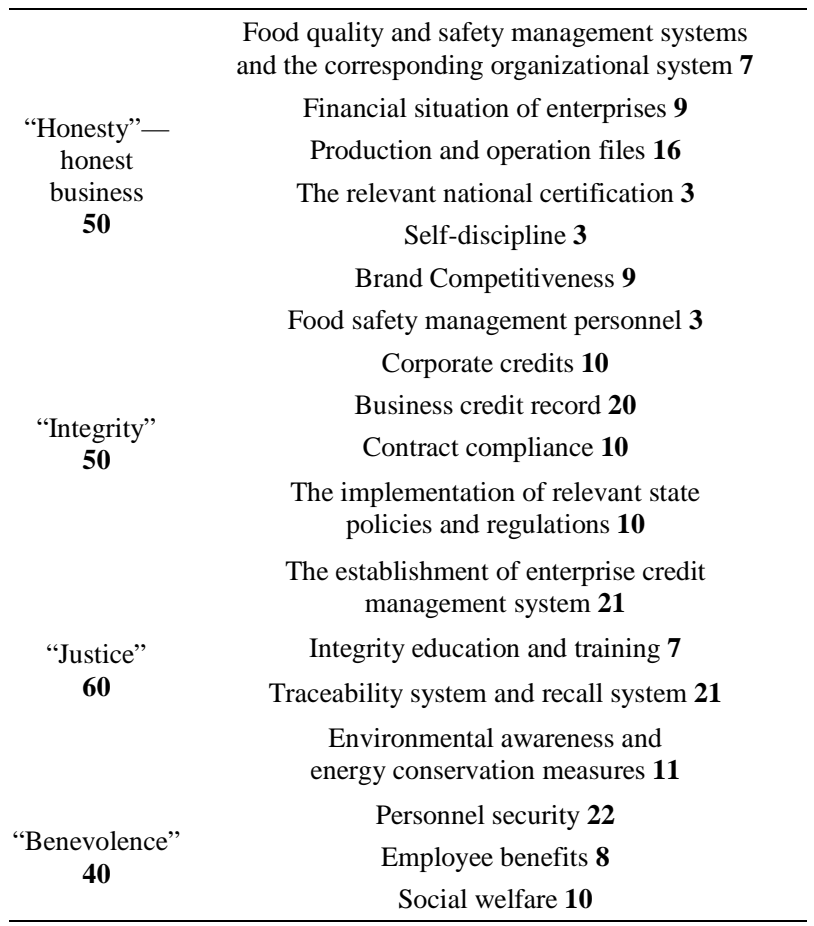

Table 7 . The integrity rating table.

\begin{tabular}{ccc}
\hline Rating & Integrity rate & Integrity \\
\hline $90-100$ & AAA & Outstanding \\
$85-90$ & AA & Excellent \\
$80-85$ & A & Fine \\
$70-80$ & BBB & Preferably \\
$60-70$ & BB & Tolerable \\
$55-60$ & B & Kind \\
$50-55$ & CCC & Poor \\
$45-50$ & CC & Not good \\
Under 45 & C & Disappointing \\
\hline
\end{tabular}

Table 8 . food brand enterprise integrity behavior evaluation score.

\begin{tabular}{ccc}
\hline Evaluation items & Standard scores & Actual score \\
\hline $\mathrm{B}_{11}$ & 7 & 6 \\
$\mathrm{~B}_{12}$ & 9 & 7 \\
$\mathrm{~B}_{13}$ & 16 & 13 \\
$\mathrm{~B}_{14}$ & 3 & 3 \\
$\mathrm{~B}_{15}$ & 3 & 3 \\
$\mathrm{~B}_{16}$ & 9 & 7 \\
$\mathrm{~B}_{17}$ & 3 & 2.5 \\
$\mathrm{~B}_{1}$ Brief sum-up & 50 & 41.5 \\
$\mathrm{~B}_{21}$ & 10 & 9 \\
$\mathrm{~B}_{22}$ & 20 & 18 \\
$\mathrm{~B}_{23}$ & 10 & 9 \\
$\mathrm{~B}_{24}$ & 10 & 9 \\
$\mathrm{~B}_{2}$ Brief sum-up & 50 & 45
\end{tabular}

Table 9. food brand enterprise integrity potential evaluation score.

\begin{tabular}{ccc}
\hline Evaluation items & Standard scores & Actual score \\
\hline $\mathrm{B}_{31}$ & 21 & 19 \\
$\mathrm{~B}_{32}$ & 7 & 5 \\
$\mathrm{~B}_{33}$ & 21 & 18 \\
$\mathrm{~B}_{34}$ & 11 & 9 \\
$\mathrm{~B}_{3}$ Brief sum-up & 60 & 51 \\
$\mathrm{~B}_{41}$ & 22 & 20 \\
$\mathrm{~B}_{42}$ & 8 & 6.5 \\
$\mathrm{~B}_{43}$ & 10 & 7.5 \\
$\mathrm{~B}_{4}$ Brief sum-up & 40 & 34 \\
\hline
\end{tabular}

\section{Conclusion}

There are three effects to establish integrity evaluation system of food brand enterprise: First is that the organization brand enterprises can carry out self-examination and self evaluation activities. Guide enterprises implement self evaluation according to the evaluation criterion. Second is to launch pilot enterprise credit assessment based on food brand enterprises. The competent department of industry organization, industry association or the third party services selects the good pilot enterprises which have a well integrity evaluation system, and gradually pushes to the food industry enterprises. Third is to standardize the integrity service organization management, improve the integrity of service and supervision, examination system and to promote the development of integrity service agencies.

\section{REFERENCES}

[1] H. Q. Xu, "A Study of the Cause and Mechanism of Food Safety Accidents of Brand Enterprise,” Modern Economic Research, Vol. 59, No. 5, 2012, pp. 62-67.

[2] K. Y. Lin, "The Credit Crisis: Problems of Chinese Enterprise Brand Strategy,” Journal of Heihe, Vol. 4, No. 5, 2005, pp. 33-35.

[3] S. Y. Zhang, "The Shape of the Integrity Brand Image of the Enterprise,” Popular Science and Technology, Vol. 11, No. 2, 2005, pp. 208-209.

[4] J. Feng, “Thinking about Brand Integrity,” The Special Economic Zones, Vol. 1, No. 6, 2006, pp. 179-180.

[5] W. Gao, "Brand-Crystalline of Credit Accumulation," Shanxi Higher School of Social Science Journal, Vol. 7, No. 2, 2008, pp. 74-76.

[6] Y. Z. Zhu and B. C. Zhou, "Research on Brand Fame Based on Integrity Culture," Productivity Research, Vol. 12, No. 4, 2010, pp. 97-98.

[7] Z. Zhang, "Honesty Is the Cornerstone of Enterprise Brand Construction," Chinese Brand and Security, Vol. 8, No. 3, 2012, pp. 46-47.

[8] “The Light Industry Standard of the People's Republic of 
China,” QB/T4112-2010, Credit Evaluation Norms for Food Enterprises.

[9] G. Z. Yue, "Research on the Construction of Enterprise Credit Evaluation System,” Ph.D. Thesis, Tianjing University, Tianjing, 2011.

[10] X. Y. Wu, "Shijiazhuang City Food Safety Credit System," Ph.D. Thesis, Hebei University of Science and Technology, 2012.

[11] J. Lu, Z. X. Zhang and Q. Q. Yang, "Co-Branding to Enhance Food Brand Integrity,” Business Economics and
Management, Vol. 1, 2011, pp. 76-85.

[12] Z. W. Su, “Oriental Management Tutorial," Shanghai Finance University Press, Shanghai, 2009, p. 143.

[13] W. Kang, "Brand and Integrity," Journal of China Youth University for Political Science, Vol. 6, No. 2, 2002, pp. 65-70.

[14] D. X. Peng and C. Y. Zhou, “Analysis of Food Enterprise Credit Condition Based on Fuzzy Comprehensive Evaluation Method," Journal of Jiamusi University (Natural Science Edition), Vol. 415, No. 3, 2013, pp. 418-424. 


\section{Appendix: Questionnaire Sample to Test the Integrity Evaluation Model of Food Brand Enterprises}

\section{Dear Sir or Madam,}

Hello!

I am a graduate student studying at Management School of Shanghai University of Engineering and Science. Now I am committed to study the integrity evaluation system of food brand enterprise. The research would have a positive significance to enhance the ability of food brand integrity, brand competitiveness and the sustainable growth of these enterprises. Here, we sincerely invite you to participate in this survey, this survey is anonymous, there is no right or wrong answer, we guarantee that all the information you provided only applies to the academic research, absolute secrecy! Please rest assured!

Graduate student in Shanghai University of Engineering and Science.

2013.10.
We first need to have your basic information:

1) Your gender: A. male B. female

2) Your age is

3) How is your qualification?

A) high school (secondary) or lower

B) Junior College

C) Undergraduate course

D) Graduate course or above

4) What is your personal average monthly consumption level?
A) Under 500 yuan
B) 501 - 1000 yuan
C) 1001 - 1500 yuan
D) 1501 - 2000 yuan
E) 2000 - 3000 yuan
F) more than 3000 yuan

Secondly, the following is a description of food brand enterprises' integrity situation. Please give your score of all related indexes.

\begin{tabular}{|c|c|c|c|}
\hline Projects & Problem description & Total score & Actual score \\
\hline \multirow{7}{*}{$\begin{array}{l}\text { "Honesty”- } \\
\text { honest business }\end{array}$} & $\begin{array}{l}\text { If the corporation have food quality and safety management systems and the } \\
\text { corresponding organizational system? }\end{array}$ & 7 & \\
\hline & How about the financial situation of enterprises? & 9 & \\
\hline & How are the production and operation files? & 16 & \\
\hline & Whether the corporation has he relevant national certification? & 3 & \\
\hline & Whether the corporation can be self-disciplined? & 3 & \\
\hline & Whether the brand have advantages? & 9 & \\
\hline & Whether the corporation has food safety management personnel? & 3 & \\
\hline \multirow{4}{*}{$\begin{array}{c}\text { "Integrity"- } \\
\text { emphasis } \\
\text { on credibility }\end{array}$} & How about the corporate credits? & 10 & \\
\hline & How about the business credit record? & 20 & \\
\hline & Whether the corporation can ensure contract compliance? & 10 & \\
\hline & Whether the corporation can implement relevant state policies and regulations? & 10 & \\
\hline \multirow{4}{*}{$\begin{array}{l}\text { "Justice"-take } \\
\text { advantage } \\
\text { of righteousness }\end{array}$} & How about enterprise credit management system? & 21 & \\
\hline & Whether the corporation has integrity education and training? & 7 & \\
\hline & Whether the corporation can take immediate action when having crisis? & 21 & \\
\hline & Whether the corporation have environmental awareness and energy conservation measures? & 11 & \\
\hline \multirow{3}{*}{ “Benevolence” } & How about personnel security? & 22 & \\
\hline & How about employee benefits? & 8 & \\
\hline & Whether the corporation committed into social welfare? & 10 & \\
\hline
\end{tabular}

